PSICOLOGIA,SAÚDE \& DOENÇAS, 2017, 18(3), 657-668

ISSN - 2182-8407

Sociedade Portuguesa de Psicologia da Saúde - SPPS - www.sp-ps.pt

DOI: http://dx.doi.org/10.15309/17psd180303

\title{
CYBERBULLIES, CYBERVICTIMS AND CYBERBULLIES-VICTIMS: DISCRIMINANT FACTORS IN PORTUGUESE ADOLESCENTS
}

\author{
Marina Carvalho (marina.carvalho@ulusofona.pt) ${ }^{1}$, Cátia Branquinho (catia.branquinho@ sapo.pt) ${ }^{2}, \&$ Margarida \\ Gaspar de Matos (mmatos@fmh.ulisboa.pt) $)^{2,3,4}$ \\ ${ }^{1}$ ISMAT Centre for Research in Psychology, Psychiatry Department of CHA, Portimão, Portugal; ${ }^{2}$ Aventura Social/ Faculty of \\ Human Kinetics/ University of Lisbon, Lisbon, Portugal; ${ }^{3}$ ISAMB/ University of Lisbon, Lisbon, Portugal; ${ }^{4}$ WJCR/ISPA/ \\ Lisbon, Portugal
}

\begin{abstract}
Enhancers of new and positive opportunities and learning, new technologies are also promoters of risks to the health and well-being of young people. Cyberbullying is one of those risks. The aim of this study was to analyse the differences between cyberbullies, cybervictims and cyberbully-victims for individual, relational and contextual factors. This is a Cross-sectional study. Results showed that cyberbully-victims reported higher alcohol consumption, as opposed to the increased drug use revealed by cyberbullies. Cybervictims reported more emotional symptoms, such as fear and sadness, and less night outs. Cyberbullies were more often involved in fights, and had an easier access to a larger amount of money and were more easy making friends, when compared to cybervictims. Based on the results, it is crucial to develop a greater awareness and education of parents and youth about the dangers of cyberbullying, together with the monitoring of technological development. A strong argument is also made related to the need of the inclusion of youth participation in the definition of public policies to prevent cyberbullying, as well as the need to focus not only in the prevention of cyber-peer related violence, but also to focus on violence-free, positive peer relationships, both virtual and in presence.
\end{abstract}

Keywords: cyberbullying, emotional symptoms, risk behaviours, relational factors, school environment, adolescents

Recebido em 05 Novembro de 2016 / Aceite em 19 de Setembro de 2017

In a technological age in which the use of new technology begins increasingly early, dominating the time and lives of many young people, new health problems emerge. Although the electronic media create new and positive social and learning opportunities, is also enhancer of some risks (David-Ferdon \& Hertz, 2007). Cyberbullying is one of those risks. Defined as an aggressive, intentional and repetitive behavior, perpetuated through new technologies (Kowalski, Limber \& Agatson, 2012; Bauman, 2013; Hutson, 2016), cyberbullying is an emerging public health problem (David-Ferdon \& Hertz, 2007; D'Auria, 2014; Selkie, Kota, Chan \& Brown, 2015; Matos \& Ferreira, 2015).

\footnotetext{
$\square$ PhD, Centre for Research in Psychology - ISMAT, Rua Estevão de Vasconcelos, 33. 8500-656 Portimão, Portugal. e-mail: marina.carvalho@ulusofona.pt
}

www.sp-ps.pt 


\section{CYBERBULLIES AND CYBERVICTIMS}

In a review of studies conducted by Garaigordobil (2011), 40-55\% of the students were somehow involved in cyberbullying behaviors, as cyberbullies, cybervictims or merely as observers: $20-50 \%$ of the students reported victimization experiences; $2-7 \%$ of these cases were severe victimization.

Even if it is a universal problem, its prevalence varies from study to study and from country to country. In a meta-analyses of the literature about the prevalence of cyberbullying compared to traditional bullying, Modecki, Minchin, Harbaugh, Guerra, and Runions (2014) found that cyberbullying is less prevalent than traditional bullying, suggesting that the form (online vs offline) may be less important than the behaviour and may reflect different methods of enacting similar behaviours. In Portugal, in the framework of the Health Behavior in School-aged Children Study (HBSC) of the World Health Organization (WHO), conducted with 6026 students from $6^{\text {th }}, 8^{\text {th }}$ and $10^{\text {th }}$ grade $(M=13.77$ years, $S D=1.68)$, results showed that $11 \%$ of the students were involved in this form of bullying (Matos, Simões, Camacho, Reis \& Equipa Aventura Social, 2015). Very similar to traditional bullying, cyberbullying has different predictors, impact on health and well-being, as well as different characteristics of the involved actors (Matos \& Ferreira, 2015)

With strong consequences in the youth well-being (Vieno et al., 2014), cyberbullying represents a serious risk to self-esteem, academic performance and emotional well-being (Cowie, 2013), promoting strong and negative emotions (Spears, Slee, Owens \& Bruce, 2009), as sadness and fear in cybervictims (Ackers, 2012), and feelings of guilt and shame on cyberbullies (Gianesini \& Brighi, 2015). Participants in cyberbullying behaviors reveal a higher economic status (Wang, Iannotti \& Nansel, 2009) holders of an upper financial capacity.

Characterized by a weak academic performance, as well as cybervictims, cyberbullies are less committed and linked to school (Baldry, Farrington \& Sorrentino, 2015). Cyberbullies have more aggressive characteristics, substances use and exclusion behaviours (Chan \& Greca, 2016). The impact of the participation in school violence related situations, tobacco, alcohol and illegal drugs use is recognized in anticipation of victimization and provocation behaviors (Pelfrey Jr. \& Weber, 2013).

According to Wang, Iannoti and Nansel (2009), cyberbullying does not relate to the number of friends, and perceived social competence is higher in cybervictims than in cyberbullies (Romera, Cano, García Fernández \& Ortega-Ruiz, 2016). A lower number of friendship relationships and optimism in their description, as well as a lower acceptance by peers (Nixon, 2014) is common in cyberbullies.

To our knowledge, there is only one study that as studied the discriminant factors between cyberbullies, cybervictims and cyberbully-victims. Bayraktar, Machackova, Dedkova, Cerna e Sevcikova, in 2015, studied a random sample of 12 to 18 years old Czech adolescents and results have shown that cyberbullies and cyberbully-victims, mostly boys, reported lower self-control and offline aggression, compared to cybervictims; cyberbully-victims scored higher on those dimensions, compared to cyberbullies.

Thus, given the inability to extinguish all the risks associated with technological advances, it is important that parents and youth are alert to the dangers of cyberbullying, and track the progress of the available tools to prevent these behaviors (D'Auria, 2014). More important than the number of hours that youth spend online, it is what exactly they do online (Gamito, Morais, Oliveira, Brito, Rosa \& Matos, 2016). Thus, so that new policies can be adapted to this reality, it is essential to understand the real needs of young people, giving priority to "their voice" in the identification of problems and solving strategies, along with their integration in the planning, implementation and evaluation of interventions aimed to their generation (Matos et al., 2015).

The goals of the present study were to analyse the differences between cyberbullies, cybervictims and cyberbullies-victims for individual, relational and contextual factors. 


\section{METHOD}

\section{Participants}

The 2014 wave of the Portuguese sample of the HBSC included 6026 adolescents, 47,7\% male, aged between 10 and 19,92 years old (mean age of 13,77 years old, $S D=1.68)$, in the $6^{\text {th }}(35.8 \%), 8^{\text {th }}(39.1 \%)$, and $10^{\text {th }}$ school year $(25.1 \%)$, randomly assigned from national schools and stratified, representing all the country.

Table 1 shows the demographic characteristics of the sample. Details on the other demographic characteristics can be found in Matos, Simões, Camacho, Reis \& Equipa Aventura Social (2015).

\section{Table 1.}

Demographic characteristics of the participants

\begin{tabular}{|c|c|c|c|c|c|c|c|}
\hline & $N$ & $\%$ & $M$ & $S D$ & Range & Skweness & Kurtosis \\
\hline \multicolumn{8}{|l|}{ Gender } \\
\hline Male & 2872 & 47.7 & & & & & \\
\hline Female & 3154 & 52.3 & & & & & \\
\hline \multicolumn{8}{|l|}{ School Grade } \\
\hline $6^{\text {th }}$ year & 2157 & 35.8 & & & & & \\
\hline $8^{\text {th }}$ year & 2358 & 39.1 & & & & & \\
\hline $10^{\text {th }}$ year & 1511 & 25.1 & & & & & \\
\hline \multicolumn{8}{|l|}{ Region } \\
\hline North & 2506 & 41.6 & & & & & \\
\hline Lisbon and Vale do Tejo & 1217 & 20.2 & & & & & \\
\hline Centre & 1031 & 17.1 & & & & & \\
\hline Alentejo & 755 & 12.5 & & & & & \\
\hline Algarve & 517 & 8.6 & & & & & \\
\hline Age & 6026 & 100 & 13.77 & 1.68 & $10-20$ & .202 & -.825 \\
\hline
\end{tabular}

\section{Measures}

The questionnaire (Currie, et al., 2012) includes a demographic data section and the assessment of school environment, alcohol, drugs and tobacco consumption, peer related violence, physical activity and hobbies, nutrition, security, psychosocial health, general symptoms, sexuality, social relationships and social support. Each questionnaire requires about 55 minutes to be administered (see Table 2). 


\section{CYBERBULLIES AND CYBERVICTIMS}

\section{Table 2.}

Items used and range

\begin{tabular}{|c|c|}
\hline Items & Range \\
\hline Smoking consumption & $1-4$ (everyday/don't smoke)* \\
\hline Alcohol consumption & $1-5$ (everyday/never)* \\
\hline Drugs consumption & $1-4$ (never/regularly) \\
\hline School involvment & $1-4($ like it very much/not at all)* \\
\hline Relationhips with peers & $1-5$ (strongly agree/strongly disagree)* \\
\hline Peers attitudes & $1-5$ (strongly agree/strongly disagree)* \\
\hline Peers acceptance & $1-5$ (strongly agree/strongly disagree)* \\
\hline Security feelings at school & $1-5$ (always/never)* \\
\hline Fear & $1-5$ (almost everyday/rarely or never)* \\
\hline Sadness & $1-5$ (almost everyday/rarely or never)* \\
\hline Rejection feelings & $1-5$ (strongly agree/strongly disagree)* \\
\hline Withdrawl at school & $\begin{array}{c}1-5 \text { (never happened during the last } 2 \text { months/several times } \\
\text { during week) }\end{array}$ \\
\hline Involvment in fights & $1-5$ (never/four times or more) \\
\hline Money & $0-500$ euros \\
\hline Friends in everyday life & $1-4$ (none/three or more) \\
\hline Virtual friends & $1-4$ (none/three or more) \\
\hline Making friends & $1-4$ (very easy/very difficult)* \\
\hline Time spent with friends after school & $0-6$ (none/ 6 days) \\
\hline Night outs & $0-7$ (none/ 7 days) \\
\hline Cyberbullying & $\begin{array}{l}0-4 \text { (never involved; cybervictim; cyberbully; cyberbully- } \\
\text { victim) }\end{array}$ \\
\hline
\end{tabular}

* reverted items.

\section{Procedure}

The schools that took part on the sampling process were randomly selected from the national schools list, and stratified by educational regions. In each school, a random selection of classes was carried out and the questionnaire was administered by the teachers in the computer room, online, assisted by the NT teachers, after parental and students' informed consent to volunteer and anonymous participation in the study. Details on the procedures for data collection in the HBSC Study can be consulted in Matos, Simões, Camacho, Reis \& Equipa Aventura Social (2015). 


\section{Statistical analysis}

SPSS 21.0 for Windows (SPSS, Chicago IL, USA) was used in order to carry out univariate ANOVAs and discriminant multivariate analyses, comparing the different groups. Post-hoc tests were performed according to Tukey method.

\section{RESULTS}

Table 3 shows the descriptive data obtained for each of the three groups, cybervictims, cyberbullies and cyberbully-victims.

\section{Table 3.}

Comparisons, according to cyberbullying status, for emotional symptoms, substances use, contextual and relational factors

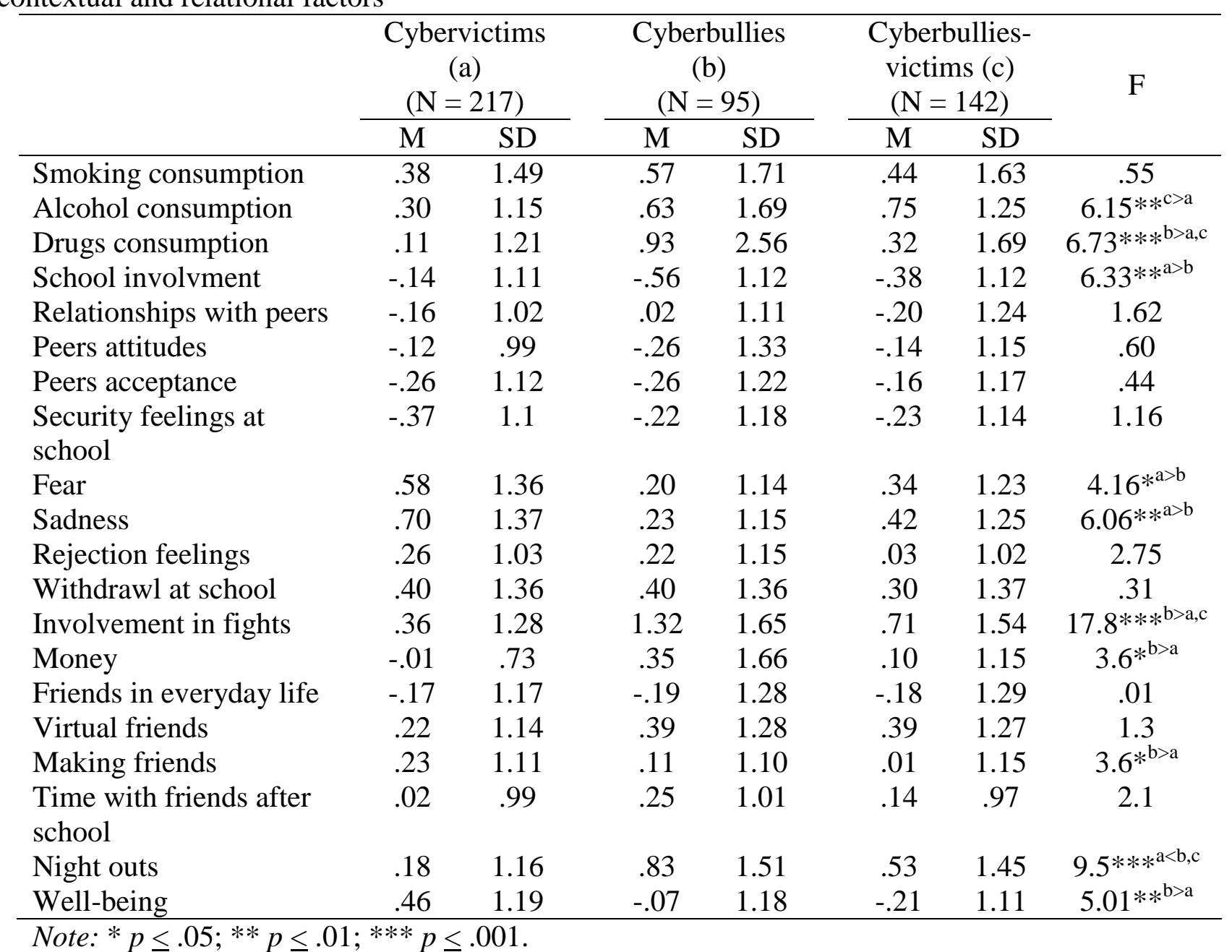

Significant differences were found in alcohol, $F(2 ; 587)=6.15, p=.002$, and drugs consumption, $F(2$; $430)=6.73, p=.0001$. Cyberbully-victims reported consuming more alcohol than victims whereas cyberbullies reported consuming more drugs compared to cybervictims and cyberbully-victims. 


\section{CYBERBULLIES AND CYBERVICTIMS}

Cybervictims reported a higher school involvement, $F(2 ; 587)=6.33, p=.002$, and less well-being, $F(2$; 530) $=5.01, p=.007$, compared to Cyberbullies.

Group differences were also found in emotional symptoms related to fear, $F(2 ; 587)=4.16, p=.016$, and sadness, $F(2 ; 587)=6.06, p=.002$. Cybervictims reported more fear and sadness compared to cyberbullies and cyberbully-victims.

Cyberbullies reported higher involvement in fights, $F(2 ; 582)=17.8, p=.0001$, compared to cybervictims and cyberbully-victims, having access to higher amounts of money, $F(2 ; 491)=3.6, p=.026$, and making friends more easily, $F(2 ; 524)=3.6, p=.013$, compared to cybervictims.

Finally, cyberbullies and cyberbully-victims reported having more night outs, $F(536)=9.5, p=.0001$, than cybervictims.

A multivariate discriminant analysis was carried out, using stepwise method, allowing to successfully discriminate the three groups, and showing one statistically discriminant function, Wilks' $\lambda=.86 ; \chi^{2}(6)=$ 52.486; $p=.0001$. The second discriminant function was not statistically significant.

The coordinates of the centroides for the three groups are presented in Table 4.

Table 4.

Centroides coordinates for the significant discriminant function

\begin{tabular}{lc}
\hline & $F 1$ \\
\hline Cybervictims & .344 \\
Cyberbullies & -.620 \\
Cyberbullies-victims & -.278 \\
\hline
\end{tabular}

According to these coordinates, Figure 1 represents the three groups (cyberbullies, cybervictims and cyberbully-victims), from their centroides within the discriminant function. 


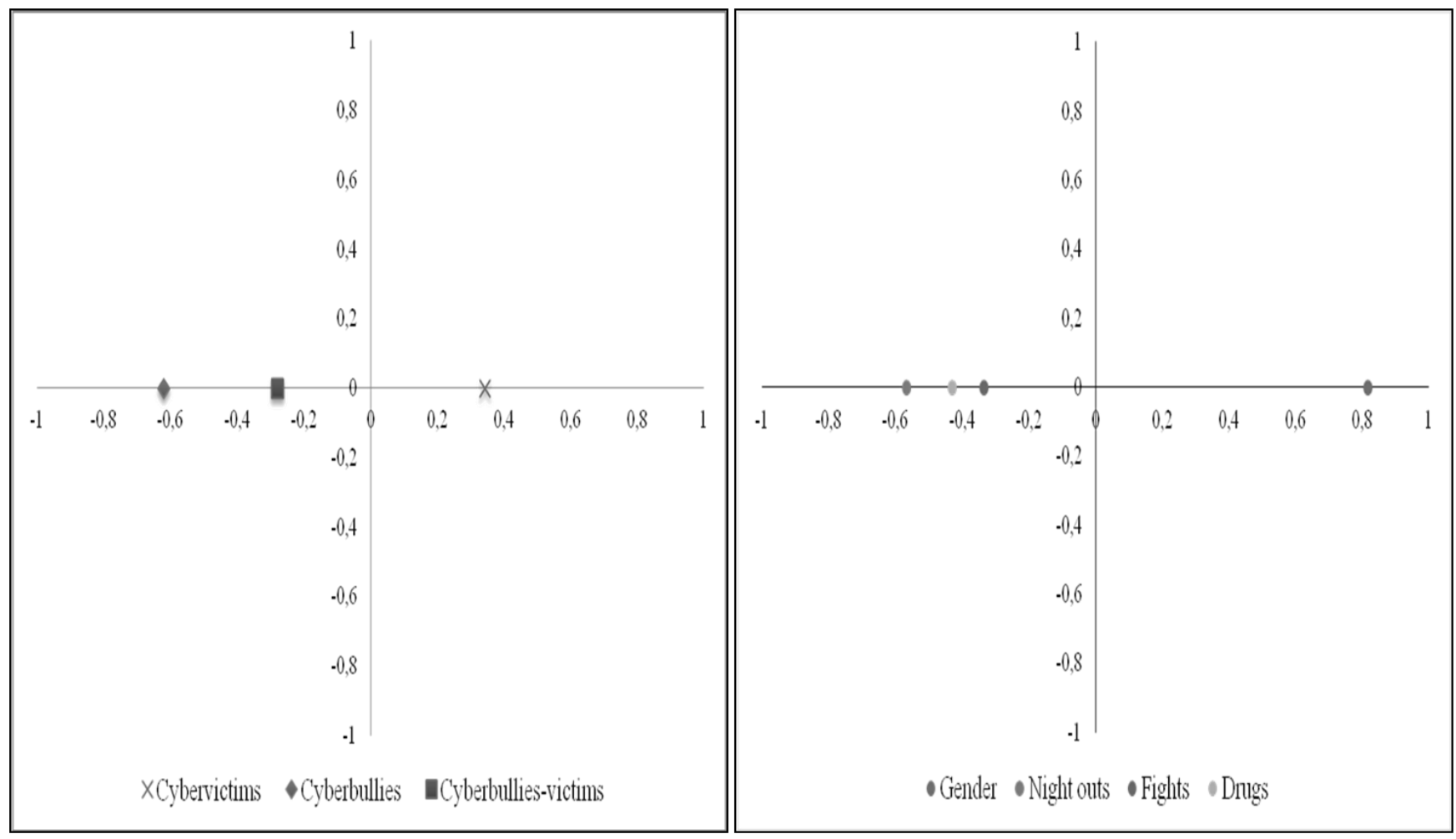

Figure 1.

Graphical representation of the groups based on the centroides values and of the discriminative variables The graphical representation of the function discriminated the three groups. Cybervictims are graphically represented on the positive side of the function. Cyberbullies and cyberbully-victims are represented on the negative side of the function. These results show that the discriminant function discriminated cybervictims form cyberbullies and cyberbully-victims.

The description of the discriminant function from the studied variables ordered by the magnitude of the correlations with the discriminant function can also be seen in Figure 1. According to Hair, Anderson, Tatham and Black (1998), we considered correlations above 0.30 statistically significant.

Thus, the first function was defined on the positive side for gender and, on the negative side, for nights out, drugs consumption and involvement in fights.

Additionally, Table 5 shows that the analysis of the discriminant function indicated that $84.4 \%$ of cybervictims, $17.6 \%$ of cyberbullies and $29 \%$ of cyberbully-victims were correctly classified. The global results of the classification, with $56.1 \%$ of the participants correctly classified, have shown that gender discriminated cybervictims from cyberbullies and cyberbully-victims, that nights out and drugs consumption discriminated cyberbullies from cyberbully-victims and cybervictims and, finally, that involvement in fights discriminated cyberbully-victims from cyberbullies and cybervictims. 


\section{CYBERBULLIES AND CYBERVICTIMS}

Table 5.

Matrix structure

\begin{tabular}{ll}
\hline & $\mathrm{F} 1$ \\
\hline Gender & $.818^{*}$ \\
Night Outs & $-.567^{*}$ \\
Involvement in fights & $-.335^{*}$ \\
Making friends & -.262 \\
Money & -.261 \\
Well-being & -.206 \\
Liking school & .127 \\
Drugs consumption & $-.429^{*}$ \\
Alcohol & -.212 \\
Sadness & .129 \\
Fear & .090 \\
\hline
\end{tabular}

* correlation values superior to .30 between the variable and the discriminant function.

Table 6.

Classification results

\begin{tabular}{lccc}
\hline & \multicolumn{2}{c}{ Predicted group membership (\%) } \\
\cline { 2 - 4 } Original & Cybervictims & Cyberbullies & $\begin{array}{c}\text { Cyberbullies- } \\
\text { victims }\end{array}$ \\
\hline Cybervictims & & 2.4 & 13.3 \\
Cyberbullies & 51.4 & 17.6 & 30.9 \\
Cyberbullies- & 62.9 & 8.1 & 29 \\
victims & & & \\
\hline
\end{tabular}

$56.1 \%$ of the original grouped cases correctly classified.

\section{DISCUSSION}

Resulting from the emergence of new technologies, the dependence of the new tools of connectivity and growing of online disinhibition (Aboujaoude, Savage, Starcevic \& Salame, 2015), cyberbullying constitutes currently an universal health risk, strongly influenced by personal and contextual factors (Casas, Del Rey \& Ortega-Ruiz, 2013).

In this research, in order to foster greater knowledge, was supported the development of new interventions or adapt existing ones, an analysis of the differences was carried out, between the different actors involved in cyberbullying behaviours, cyberbullies, cybervictims and cyberbully-victims, regarding to their individual, relational and contextual factors (Matos \& Ferreira, 2015).

In present study, statistically significant differences were found for alcohol and drugs consumption. Cyberbully-victims reported drinking more alcohol than cybervictims, and cyberbullies reported consuming more drugs and involving fights compared to cybervictims and cyberbully-victims. Youth who perpetuate aggressive behaviors against their peers, excludes them socially, and are clearly more aggressive, report more often substance use (Chan \& Greca, 2016) or an increase in its use. Cyberbullies reveal aggressive and violent behaviors (Nixon, 2014), contrasting with the emotional symptoms of fear and sadness, reported by 
victims. Promoter of strong and negative emotional behaviors (Spears, Sleep, Owens \& Bruce, 2009), cyberbullying hinders the request for help of victims (Ackers, 2012).

Compared to cyberbullies, cybervictims are characterized by less facility in making friends, have poor social skills (Baldry, Farrington \& Sorrentino, 2015) and scarce relationships with their peer group (Antoniadou, Kokkinos \& Markos, 2016). Despite they report a greater school involvement than cyberbullies (Baldry, Farrington \& Sorrentino, 2015), the perception of lower social support (Calvete, Orue, Estévez, Villardón \& Paddila, 2010) and the relational problems, as the lack of close friends or significant relations (Gross, Juvonen \& Gable, 2002), contribute to a lower perception of well-being.

Cyberbullies condition is associated with a greater easiness of access to higher amounts of money, supporting the idea that a higher socio-economic status increases the risk of involvement in cyberbullying behaviors, quite possibly due to the availability of technological equipment (Wang, Iannoti \& Nansel, 2009). Young people with a lower socioeconomic status are more likely to be cybervictims (Sampasa-Kanyinga \& Hamilton, 2015). Knowing that sooner youth start using the internet and electronic devices, faster they become targets (Baldry, Farrington \& Sorrentino, 2016), these results prove to be urgent the adoption of prevention measures to this behavior.

On the basis of a multidimensional perspective, focused on the involvement of youth in the process of identification of their necessities and proposals for their problems (Matos, 2014; Matos, 2015; Matos et al., 2015); the identification of protecting factors (communication with family, school sense of belonging, teachers' support, neighborhood sense of belonging, and the fathers role) (Chester, Magnusson, Klemera, Spencer \& Brooks, 2016); the adaptation or development of school programs to prevent bullying, focusing not only on this traditional form of violence but also in cyberbullying (Brown, Demaray \& Secord, 2014); a greater awareness and education of youth (Alim, 2016), as well as higher alert to the dangers by parents (D'Auria, 2014); and the use of technological solutions, identified by young people as the most effective strategy in combating cyberbullying (Kowalski, Giumetti, Schroeder \& Lattaner, 2014), are an efficient and perdurable work that can be carried through.

A strong argument is also made related to the need to include young people participation in the definition of public policies to prevent cyber peer-related violence, as well as a need to focus not only in the prevention of cyber-peer related violence, but also to focus on violence-free, positive peer relationships, both virtual and in presence.

\section{ACKNOWLEDGMENTS}

This research was supported by the Ministry of Health. The authors would like to acknowledge the collaboration of the HBSC Portuguese team integrated in the Social Adventure Projects of the Faculty of Human Kinetics, University of Lisbon, for data collection. Branquinho, C. receives a $\mathrm{PhD}$ grant from the University of Lisbon (UL) (Grant Number 800178).

\section{REFERENCES}

Aboujaoude, E., Savage, M. W., Starcevic, V., \& Salame, W. O. (2015). Cyberbullying: Review of an Old

Problem Gone Viral. Journal of Adolescent Health, 57(1), 10-18. doi: 10.1016/j.jadohealth.2015.04.011 


\section{CYBERBULLIES AND CYBERVICTIMS}

Ackers, M. J. (2012). Cyberbullying: through the eyes of children and young people. Educational Psychology in Practice, 28(2), 141-157. doi: 10.1080/02667363.2012.665356

Alim, S. (2016). Cyberbullying in the World of Teenagers and Social Media: A Literature Review. International Journal of Cyber Behavior, Psychology and Learning, 6(2), 68-95. doi: 10.4018/IJCBPL.2016040105

Antoniadou, N., Kokkonos, C.M., \& Markos, A. (2016). Possible common correlates between bullying and cyber-bullying among adolescents. Psicología Educativa, 22 (1), 27-38. doi: 10.1016/j.pse.2016.01.003

Bauman, S.M. (2013). Cyberbullying: What Does Research Tell Us? Theory Into Practice, 52(4), 249-256. doi: $10.1080 / 00405841.2013 .829727$

Baldry, A.C., Farrington, D.P., \& Sorrentino, A. (2016). Cyberbullying in youth: A pattern of disruptive behavior. Psicología Educativa, 22(1), 19-26. doi: 10.1016/j.pse.2016.02.001

Baldry, A.C., Farrington, D.P., \& Sorrentino, A. (2015). “Am I at risk of cyberbullying”? A narrative review and conceptual framework for research on risk of cyberbullying and cybervictimization: the risk and needs assessment approach. Aggression and Violent Behavior, 23, 36-51. doi: 10.1016/j.avb.2015.05.014

Bayraktar, F., Machackova, H., Dedkova, L., Cerna, A., \& Ševčíková, A. (2015). Cyberbullying: The discriminant factors among cyberbullies, cybervictims and cyberbully-victims in a Czech adolescente sample. Journal of Interpersonal Violence, 30, 3192 - 3216.

Brown, C.F., Demaray, M.K., \& Secord, S.M. (2014). Cyber victimization in middle school and relations to social emotional outcomes. Computers in Human Behavior, 35, 12-21. doi: 10.1016/j.chb.2014.02.014

Calvete, E., Orue, I., Vllardón, L., \& Padilla, P. (2010). Cyberbullying in adolescents: Modalities and aggressors' profile. Computers in Human Behavior, 26(5), 1128-1135. doi:10.1016/j.chb.2010.03.017

Casas, J.A., Del Rey, R., \& Ortega Ruiz, C. (2013). Bullying and cyberbullying: Convergent and divergent predictor variables. Computers in Human Behavior, 29, 3, 580-584. http://dx.doi.org/10.1016/j.chb.2012.11.015

Chan, S.F., \& La Greca, A.M. (2016). Cyber Victimization and Aggression: Are They Linked with Adolescent Smoking and Drinking?. Child Youth Care Forum, 45, 47. doi:10.1007/s10566-015-9318xCalvete

Chester, K., Magnusson, J., Klemera, E., Spencer, N., \& Brooks, F. (2016). The mitigating role of ecological health assets in adolescent cyberbullying victimization. Youth \& Society, 1-27. doi:

10.1177/0044118X16673281

Cowie, H. (2013).The impact of cyberbullying on young people's emotional health and well-being. The Psychiatrist, 37(5), 167-170. doi: 10.1192/pb.bp.112.040840

Currie, C. et al. (Eds.) (2012). Social determinants of health and well-being among young people. Health Behaviour in School-aged Children (HBSC) study: international report from the 2009/2010 survey. Copenhagen: WHO Regional Office for Europe (Health Policy for Children and Adolescents, No. 6).

D'Auria, J. P. (2014). Cyberbullying Resources for Youth and Their Families. Journal of Pediatric Health Care, 28(2), 19-22. doi: 10.1016/j.pedhc.2013.11.003

David-Ferdon, C., \& Hertz, M.F. (2007). Electronic media, violence, and adolescents: an emerging public health problem. Journal of Adolescence Health, 41(6), 1-5. doi:10.1016/j.jadohealth.2007.08.020

Gamito, P.S., Morais, D.G., Oliveira, J.G., Brito, R., Rosa, P.J., \& Matos, M.G. (2016). Frequency is not enough: Patterns of use associated with risk of Internet addiction in Portuguese adolescents. Computers in Human Behavior, 58, 471-479. doi:10.1016/j.chb.2016.01.013 
Garaigordobil, M. (2011). Prevalencia y consecuencias del cyberbullying: una revision [Prevalence and consequences of cyberbullying: a review]. International Journal of Psychology and Psychological Therapy, 11(2), 233-254.

Gianesini, G. \& Brighi, A. (2015). Cyberbullying in the Era of Digital Relationships: The Unique Role of Resilience and Emotion Regulation on Adolescents' Adjustment. In S.L. Blair, P.N. Claster, \& S.M. Claster (Eds.) Technology and Youth: Growing Up in a Digital World (pp.1-46). United Kingdom: Emerald Group Publishing Limited.

Gross, E. F., Juvonen, J., \& Gable, S. L. (2002). Internet Use and Well-Being in Adolescence. Journal of Social Issues, 58, 75-90. doi: 10.1111/1540-4560.00249

Hair, J.F. Jr., Anderson, R.E., Tatham, R.L., \& Black, W.C. (1998). Multivariate data analysis (5 ${ }^{\text {th }}$ Ed.). Upper Saddle River, NJ: Prentice Hall.

Hutson, E. (2016). Cyberbullying in Adolescence: A Concept Analysis. ANS. Advances in Nursing Science, 39(1), 60-70. doi: 10.1097/ANS.0000000000000104

Kowalski, R. M., Giumetti, G. W., Schroeder, A. N., \& Lattanner, M. R. (2014). Bullying in the digital age: a critical review and meta-analysis of cyberbullying research among youth. Psychological Bulletin, 140(4), 1073-137. doi: 10.1037/a0035618

Kowalski, R. M., Limber, S. E., \& Agatston, P. W. (2012). Cyberbullying: Bullying in the digital age (2 Ed.). Malden: Wiley-Blackwell.

Matos, M.G. (2014). Novos rumos na educação e promoção da saúde a partir de uma reflexão sobre a intervenção com crianças e adolescentes no trabalho do Aventura Social. [New directions in education and health promotion from a reflection on intervention with children and adolescents in the work of the Social Adventure]. Saúde e Tecnologia, 12, 5-7. ISSN: 1646 -9704

Matos, M.G., Simões, C., Camacho, I., Reis, M. \& Equipa Aventura Social (2015). A Saúde dos Adolescentes Portugueses em Tempos de Recessão - Dados Nacionais do Estudo HBSC de 2014 ? [The Health of Portuguese Adolescents in Times of Recession - National Data from 2014 HBSC study]. Lisboa: IHMT/UNL, FMH/UL. ISBN: 978-989-98346-1-3

Matos, M.G., et al. (2015). "Dream Teens" - Adolescentes autónomos, responsáveis e participantes ["Dream Teens" - Autonomous, responsible and participative adolescents]. Journal of Child and Adolescent Psychology, 6(2), 47-58.

Matos, M.G. (2015). Adolescentes: navegação segura por águas desconhecidas. [Adolescents: safe navigation through unknown waters]. Lisboa: Coisas de Ler.

Matos, M.G., \& Ferreira, M. (2013). Nascidos digitais: Novas linguagens, Lazer e Dependências [Born Digital: New languages, Leisure and Dependencies]. Lisboa: Coisas de Ler.

Modecki, K. L., Minchin, J., Harbaugh, A. G., Guerra, N. G., \& Runions, K. C. (2014). Bullying prevalence across contexts: A meta-analysis measuring cyber and traditional bullying. Journal of Adolescent Health, 55, 602 - 611. doi: 10.1016/j.jadohealth.2014.06.007

Nixon, C. L. (2014). Current perspectives: the impact of cyberbullying on adolescent health. Adolescent Health, Medicine and Therapeutics, 5, 143-158. doi: 10.2147/AHMT.S36456

Pelfrey Jr., W.V., \& Weber, N.L. (2013). Keyboard Gangsters: Analysis of Incidence and Correlates of Cyberbullying in a Large Urban Student Population. Deviant Behavior, 34(1), 68-84. doi: 10.1080/01639625.2012.707541 


\section{CYBERBULLIES AND CYBERVICTIMS}

Romera, E.M., Cano, J., García-Fernández, C., \& Ortega-Ruiz, R. (2016). Cyberbullying: Social Competence, Motivation and Peer Relationships, Comunicar, 24, (48) 71-79. doi: http://dx.doi.org/10.3916/C48-2016-07

Sampasa-Kanyinga, H., \& Hamilton, H.A. (2015). Use of Social Networking Sites and Risk of Cyberbullying Victimization: A Population-Level Study of Adolescents. Cyberpsycholy, Behavior, and Social Networking, 18(12), 704-710. doi: 10.1089/cyber.2015.0145

Selkie, E.M., Kota, R., Chan, Y., \& Moreno, M. (2015). Cyberbullying, Depression, and Problem Alcohol Use in Female College Students: A Multisite Study. Cyberpsychology, Behavior, and Social Networking, 18(2), 79-86. doi: 10.1089/cyber.2014.0371

Spears, B., Slee, P., Owens, L., \& Bruce, J. (2009). Behind the scenes and screens: Insights into the human dimension of covert and cyberbullying. Zeitschrift für Psychologie/ Journal of Psychology, 217(4), 189196. doi: 10.1027/0044-3409.217.4.189

Vieno, A., Gini, G., Lenzi, M., Pozzoli, T., Canale, N., \& Santinello, M. (2014). Cybervictimization and somatic and psychological symptoms among Italian middle school students. European Journal of Public Health, 26(2), 1-5. doi: 10.1093/eurpub/cku191

Wang, J., Iannoti, R.J., \& Nansel, T.R. (2009). School Bullying Among US Adolescents: Physical, Verbal, Relational and Cyber. Journal of Adolescent Health, 45(4), 368-375. doi:10.1016/j.jadohealth.2009.03.021. 